\title{
Diseases of the eye of farmed shrimp Penaeus monodon
}

\author{
Paul T. Smith* \\ Centre for Sustainable Aquaculture, University of Western Sydney, PO Box 555, Campbelltown, \\ New South Wales 2560, Australia
}

\begin{abstract}
Lesions were found in the eyes of cultured shrimp Penaeus monodon that displayed non-specific signs of disease, including lethargy, dark pigmentation, brown gills, empty midgut, anorexia, white tail muscle, necrosis of uropods and fouled cuticle. Eye lesions were associated with sexual development in moribund shrimp in at least 1 disease event. Suppurative inflammation, granuloma and malacia were observed in histological examination of the eye and the causative agents of lesions appear to be Vibrio spp. and a rod-shaped virus (similar to Lymphoid Organ Virus, GillAssociated Virus [GAV] and Yellow-Head Virus). Suppurative inflammation was characterised by edema, infiltration of haemocytes and local sites of abscesses. Eyes with granuloma usually appeared white in pond-side examinations, and histology showed that fibrous tissue replaced ommatidia, ganglia and internal structures of the eye. Malacia of the eye was characterised by necrosis of nervous tissue, vacuolation and vascular proliferation in the medulla ganglia. Levels of presumptive Vibrionaceace were high in moribund specimens and Gram-negative rods were observed in some specimens as free particles in the interstitial fluid and haemolymph in the eye. Transmission electron microscopy showed that nerve cells in the fasciculated zone (near the basement membrane) contained cytoplasmic vesicles ( 1 to $3 \mu \mathrm{m}$ in diameter) with particles (15 to $26 \mathrm{~nm}$ in diameter) and rodshaped nucleocapsids. The rods were similar to those of GAV and were 130 to $260 \mathrm{~nm}$ long, 10 to $16 \mathrm{~nm}$ in diameter and had helical symmetry with a screw-like thread (2.4 to $3.5 \mathrm{~nm}$ pitch). Also, unidentified enveloped virions, averaging $74 \mathrm{~nm}$ in diameter, were observed in cytoplasmic vesicles in the fasciculated zone. In conclusion, it is suggested that bacterial and viral infections of the eye could result in impaired neuroendocrine functions, which may cause a range of clinical signs of disease.
\end{abstract}

KEY WORDS: Prawn $\cdot$ Shrimp $\cdot$ Penaeus monodon $\cdot$ Eye $\cdot$ Neurosecretion $\cdot$ Virus $\cdot$ Bacteria $\cdot$ Vibrio spp.

Resale or republication not permitted without written consent of the publisher

\section{INTRODUCTION}

In the last 20 yr of coastal shrimp culture there has been considerable progress in describing a range of bacterial diseases (Anderson et al. 1988, Lightner 1988, Lavilla-Pitogo et al. 1990) and viral diseases (Johnson 1983, Lightner 1985, Lightner \& Redman 1990, Owens et al. 1991, Lightner et al. 1992, Boonyaratpalin et al. 1993, Owens 1993, Takahashi et al. 1994, Flegel et al. 1995, Hasson et al. 1995, Lightner 1996, Spann et al. 1997). Diagnosis usually involves examination of lesions

*E-mail: pt.smith@uws.edu.au in a variety of tissues of moribund shrimp (Lightner 1996), but pathologies of the eye are rarely reported. In one disease, the fungus Fusarium solani can cause atrophy of eye tissue from the cuticle to the retinal layer and medulla (Laramore et al. 1977, Colorni 1990, Giorgetti 1990). However, infections of F. solani are not restricted to the eye; expansive melanised lesions caused by $F$. solani can be found in all appendages (antennae, pereiopods, uropods and telson) and are often associated with abrasions and wounds (Solangi \& Lightner 1976, Lightner 1996). This paper reports on previously undescribed pathologies of the eye of $P e$ naeus monodon. 
The eye is a highly significant structure in shrimp and crustaceans because it is responsible for vision as well as secretion of hormones and neurohormones. In fact the main neurohaemal organ is the sinus gland complex, which is located within the ganglionic region of the eye. It regulates either directly or indirectly most aspects of crustacean metabolism and function (Charmantier \& Charmantier-Daures 1998). Bern \& Hagadorn (1965) listed 6 areas of crustacean endocrinology that are regulated by the sinus gland: (1) lightadaptive responses of retinal pigments, (2) somatic pigmentation, (3) moulting, regeneration and growth, (4) reproduction, (5) metabolism, and (6) heart rate.

In view of the importance of the eye, this study investigated mortalities of Penaeus monodon at Australian farms and focused on the condition of the eyes of affected specimens. The investigation aimed to determine the types of lesions that occurred in the eye, to identify pathogenic organisms in the eye and to consider the association between eye abnormalities and clinical signs of disease.

\section{MATERIALS AND METHODS}

Study sites. Shrimp mortalities were investigated at 5 commercial shrimp farms: Farms A, B, D and E were near Cairns, Queensland (a sub-tropical region, $15.30^{\circ} \mathrm{S}, 145.16^{\circ} \mathrm{E}$ ) and Farm $\mathrm{C}$ was on the Clarence River, NSW (a warm temperate region, $29.26^{\circ} \mathrm{S}$, $153.23^{\circ} \mathrm{E}$ ). All farms grew Penaeus monodon that were purchased from hatcheries, which used wild spawners caught off-shore from Cairns. DNA probes were not normally used in the hatcheries to screen for viruses. Postlarvae (PL, 15 to 20 d) were stocked in earthen ponds at densities of 20 to $45 \mathrm{~m}^{-2}$. The farms near Cairns usually grew 2 crops $\mathrm{yr}^{-1}$, while the farm on the Clarence River grew 1 crop $\mathrm{yr}^{-1}$. Ponds were 1.2 to $1.8 \mathrm{~m}$ deep and 4 to 8 aerators were placed around the periphery of each pond. Ponds varied in size from 0.7 to $1.5 \mathrm{ha}$, and total areas for each farm ranged from 10 to 40 ha. Imported and local pellets were fed to shrimp 3 to 4 times $\mathrm{d}^{-1}$ and feed trays were used to check on consumption. Generally the farms harvested 3000 to $6500 \mathrm{~kg} \mathrm{ha}^{-1} \mathrm{crop}^{-1}$ and feed conversion ratios (FCRs) ranged between 1.8 and 2.5 unless disease outbreaks occurred.

Collection and examination of specimens. During outbreaks of disease, shrimp were collected by hand from the edge of ponds and by cast net from deeper waters. Collection was carried out during daylight hours; usually between 10:00 and 15:00 h. Shrimp were initially held in aerated buckets of pond water and examined for gross abnormalities and signs of disease. Within $1 \mathrm{~h}$ of collection, shrimp were either pre- served whole ( $\mathrm{n}=3$ to 10 pond $^{-1}$ ) or dissected and their tissues preserved ( $\mathrm{n}=3$ to 10 pond $^{-1}$ ). Eyes, hepatopancreas, midgut, gills and sections of the cuticle were routinely preserved in $2.5 \%$ glutaraldehyde in phosphate buffer (containing $\mathrm{NaCl}$, sucrose) and Davidson's alcohol formalin acetic acid fixative (Lightner 1996). Standard histological techniques were used for paraffin embedding and sectioning of shrimp tissue (p. 4 \& 5 in Bell \& Lightner 1988). Sections were stained by standard methods (p. 6 in Bell \& Lightner 1988) with Mayer's hematoxylin and Phloxine/eosin (H\&E) or Brown and Brenn Gram stain. Slides from weak and healthy shrimp were examined by light microscopy and comparisons were made with photomicrographs of normal shrimp tissue (Nicol \& Yan 1982, p. 26-33 in Bell \& Lightner 1988).

To examine eye tissue with a transmission electron microscope (TEM), samples were fixed in $2.5 \%$ glutaraldehyde in phosphate buffer (Lightner 1996), stained with $1 \%$ osmium tetroxide and prepared in araldite blocks using a protocol for marine specimens (Vesk \& Rees 1986). Thin sections (70 to $80 \mu \mathrm{m}$ ) were cut with a diamond knife, supported on coated copper grids (200 $\mathrm{mm}$ mesh) and stained for $10 \mathrm{~min}$ in saturated solutions of uranyl acetate (50\% ethanol) then Reynolds' lead citrate (Vesk \& Rees 1986).

Measurement of pond conditions and bacteriology. Field instruments were used to measure $\mathrm{pH}$, redox potential, salinity, temperature, dissolved oxygen, Secchi disk visability, water colour, ammonia and available phosphate (Smith 1995, 1996a). Water samples were usually collected as water overflowed from ponds into the drains, while bottom sediments were collected $5 \mathrm{~m}$ from the edge of ponds. Levels of bacteria in water and sediment were determined by preparing serial dilutions, inoculating duplicate plates of TCBS agar (Oxoid) and Marine Agar (Difco) for presumptive Vibrionaceae and heterotrophic bacteria, respectively, and counting colonies after 2 to $3 \mathrm{~d}$ (Cameron et al. 1988).

Also, levels of bacteria were determined for shrimp tissue and haemolymph. Tissue samples were prepared from shrimp that had been surface sterilised with $95 \%$ ethanol then sacrificed by rapidly removing the carapace and anterior region (including the brain) in one movement. Instruments that had been cleaned and sterilised in $95 \%$ ethanol were used to remove whole organs (hepatopancreas, eye) and tissues (gills, muscle). The weight of dissected material was estimated and then the tissue was added to $5 \mathrm{ml}$ sterile saline $(1.2 \%)$. A sterilised plastic plunger was used to homogenise the tissue for $2 \mathrm{~min}$, following which serial dilutions were prepared. Haemolymph ( 0.1 to $0.3 \mathrm{ml}$ ) was collected by irrigating the cuticle with $95 \%$ alcohol and inserting a sterile syringe into 
the ventral haemal sinus (Lightner 1996). Levels of bacteria were determined for tissue samples and haemolymph by inoculating plates of TCBS agar and Marine Agar with serial dilutions and counting the colonies after 2 to $3 \mathrm{~d}$. To classify the major species of Vibrionaceae present in moribund shrimp, colonies were randomly selected from TCBS plates that had fewer than 10 colonies (i.e. highest dilutions). These isolates were classified according to results of key diagnostic traits and tests for growth on 18 sources of organic carbon (Baumann \& Schubert 1984, West \& Colwell 1984). Levels of bacteria for tissue samples are quoted in colony forming units (cfu) per gram $\left(\mathrm{cfu} \mathrm{\textrm {g } ^ { - 1 }}\right.$ ) and Student's $t$-test was used to detect differences between results for moribund and healthy specimens.

Challenge tests. Challenge tests were carried out to observe the behaviour of moribund shrimp and test for the presence of pathogens. Shrimp were challenged by injection of tissue homogenates and bacterial inocula, as well as by ingestion of diseased tissue. For tissue homogenates, healthy shrimp were injected in the tail muscle with diluted tissue sample $(0.25 \mathrm{ml})$ that had been prepared from the hepatopancreas of moribund shrimp (as described in the section above). Filtered homogenates $(0.2 \mu \mathrm{m})$ were used to test for viruses in the hepatopancreatic tissue, while unfiltered homogenates were used to test for pathogenic bacteria. For bacterial inocula, dilutions were prepared in $1.2 \%$ saline from colonies of presumptive Vibrionaceae that had been freshly isolated on TCBS plates from moribund shrimp (see 'Measurement of pond conditions and bacteriology' above). Healthy shrimp were injected in the tail muscle with $0.25 \mathrm{ml}$ of inoculum. Control shrimp were injected with $0.25 \mathrm{ml}$ of sterile saline. For ingestion, healthy shrimp were fed 2 moribund shrimp $\operatorname{tank}^{-1} \mathrm{~d}^{-1}$.

The tests were performed at farms with shrimp ( $\mathrm{n}=5$ to 9) in aerated 601 tanks. Shrimp were given minimal amounts of pellet feed once daily during the test, except for the challenge by ingestion. The tests were carried out at ambient temperature $\left(25\right.$ to $\left.30^{\circ} \mathrm{C}\right)$ using water from the farm's intake canal. Tank water was replaced daily and tests were terminated after $7 \mathrm{~d}$.

\section{RESULTS}

\section{Overview and pond-side observations}

From 1994 to 1999, a total of 6 disease outbreaks were investigated at 5 farms during the course of 28 field trips. Microscopic lesions in the eye were common ( $>50 \%$ of specimens) in 3 incidents at Farms A, B and $\mathrm{C}_{\boldsymbol{i}}$ less prevalent (5 to $10 \%$ of specimens) in 2 incidents at Farms D and $\mathrm{E}_{\text {; }}$ and absent (Septic Hepatopancreatitis Syndrome) in the other. Also, in 2 other disease events that were partially investigated, 1 specimen was collected from each farm and microscopic eye lesions were found in both cases.

In all ponds that were affected by mass mortalities of shrimp, the values for biophysical parameters were within the following ranges: dissolved oxygen, 5.5 to $7.4 \mathrm{mg} \mathrm{l}^{-1}$; $\mathrm{pH}, 7.5$ to 8.9 ; salinity, 15 to $32 \mathrm{ppt}$ temperature, 24 to $33^{\circ} \mathrm{C}_{i}$ and Secchi disc visability, 0.25 to $0.70 \mathrm{~m}$. Nutrient levels were $\left(\mu \mathrm{g} \mathrm{l^{-1 }}\right)$ : nitrate, $<40$; nitrite, <20; ammonia, <600; phosphate, <800; and silica, 500 to 4600 . Blooms of planktonic species of the cyanobacteria Oscillatoriales were dominant in 2 disease outbreaks and patches of benthic Oscillatoriales were present in the other disease events, though microalgae were the dominant phytoplankton in those instances. Levels of presumptive Vibrionaceae in pond water and sediments are summarised for some disease events in Table 1. The levels of presumptive Vibrionaceae in pond water during these outbreaks were not significantly different $(\mathrm{p}>0.10)$ from levels previously reported $\left(3.5 \times 10^{4} \pm 1.6 \times 10^{4} \mathrm{cfu} \mathrm{m}^{-1}, \mathrm{n}=131\right)$ in a long-term study of shrimp ponds at these farms (Smith 1995). Similarly, levels in sediments (Table 1) were within the range previously reported $\left(2 \times 10^{5}-5 \times 10^{6} \mathrm{cfu}\right.$ $\mathrm{ml}^{-1}$ ) for normal ponds at these farms (Smith 1998).

The first indicator of disease problems was a reduction in feed consumption. Once mortalities started to occur, feeding rates never recovered to previous levels. Shrimp mortalities occurred during the middle to late stage of growout in all incidents, when the shrimp averaged 15 to $35 \mathrm{~g}$. The largest shrimp in a pond usually died first. Weak shrimp displayed non-specific signs of disease. In the initial stages they were lethargic and had dark pigmenta-

Table 1. Levels of presumptive Vibrionaceae in water and sediment from shrimp ponds that had mortalities. Values are given as mean and range for the number of ponds tested (n), unless values are not available (na)

\begin{tabular}{|lll|}
\hline Location, year of mortalities & Vibrionaceae in water $\left(\mathrm{cfu} \mathrm{ml}^{-1}\right)$ & ${\text { Vibrionaceae in sediment }\left(\mathrm{cfu}^{-1}\right)}$ \\
\hline Farm A, 1994 & $3.0 \times 10^{4}\left(1 \times 10^{4}-6 \times 10^{4}\right)(\mathrm{n}=4)$ & na \\
Farm B, 1995 & $3.5 \times 10^{4}\left(7 \times 10^{2}-1.3 \times 10^{5}\right)(\mathrm{n}=4)$ & $2.0 \times 10^{6}\left(8 \times 10^{5}-7 \times 10^{6}\right)(\mathrm{n}=5)$ \\
Farm C, 1999 & $1.5 \times 10^{4}\left(8 \times 10^{3}-3 \times 10^{4}\right)(\mathrm{n}=4)$ & $1.2 \times 10^{6}\left(5 \times 10^{5}-9 \times 10^{6}\right)(\mathrm{n}=4)$ \\
\hline
\end{tabular}


tion, yellow or brownish gills, empty midgut, whitish tail muscle and necrosis in the tips of the uropods (tail rot). In the next stage, shrimp had fouled gills, small white hepatopancreas, barnacles or debris on the cuticle and dark brown to red pigmentation. Gills from moribund shrimp were congested mainly with diatoms (Nitzschia spp., Pleurosigma spp., Navicula spp., though there were also some cyanobacteria (Oscillatoria spp.), Leucotrix mucor, sediment and mucus. Finally, moribund shrimp moved to the banks of ponds and died. The highest rates of mortalities occurred when shrimp were due to moult.

In one disease event at Farm C in 1998 a distinguishing feature of the moribund shrimp was that female shrimp (30 to $57 \mathrm{~g}$ ) had well-developed green ovaries and males (>25 g) had large white testes. Over 50 moribund female shrimp were examined and all had green ovaries. In comparison, more than 50 grossly healthy shrimp of similar size were caught by cast net from the same pond and all had translucent thin ovaries. It should be noted that sexual development of female Penaeus monodon ( $<7$ mo old) was observed in one earlier disease event ( 25 to $55 \mathrm{~g}$ shrimp) by the author. However, histological examination was not carried out.

A range of treatments and management practices were unsuccessfully used by farmers during these outbreaks. These included increasing the rate of water exchange from 5 to $30 \% \mathrm{~d}^{-1}$, applying antiseptic (benzalkonium chloride), lime, medicated feed (containing oxytetracycline), formalin, algicide (simerzine), fertiliser (nitram), probiotic bacteria, zeolite and teaseed cake.

\section{Suppurative inflammation of the eye}

Suppurative inflammation of the eye was characterised by edema, infiltration of haemocytes and localised sites of abscesses. For example, the junction between the fasciculated zone and the lamina ganglionaris in normal eyes is usually narrow $(20 \mu \mathrm{m})$ and free of haemocytes. However, in Fig. 1 the junction is 50 to $100 \mu \mathrm{m}$ wide and infiltrated with eosinophilic fluid and inflammatory cells. A closer examination of this region reveals necrotic and pyknotic cells and disorganisation of the normal structure of the nerve and glial fibres of the lamina ganglionaris (Fig. 2). Blood vessels and lacunae of the lamina ganglionaris were considerably enlarged and lined with haemocytes. Abscesses with necrotic and pyknotic cells could be found in the dioptic region (Fig. 3) and other regions within the eye. Suppurative inflammation was a common condition ( $>50 \%$ of moribund shrimp) at Farm A in 1994 and Farm B in 1995, and a minor condition $(10 \%)$ at Farms C, D and E in 1999.

\section{Granuloma of the eye}

Granuloma was found in eyes that usually appeared white in pond-side examinations and those eyes often had a melanised region on the cuticle. This type of pathology occurred in 2 to $5 \%$ of moribund shrimp at Farms A in 1994, B in 1995 and C in 1999. It was characterised by replacement of ommatidia, ganglia and internal structures of the eye with eosinophilic fibrous tissue containing melanised nodules of haemocytes,

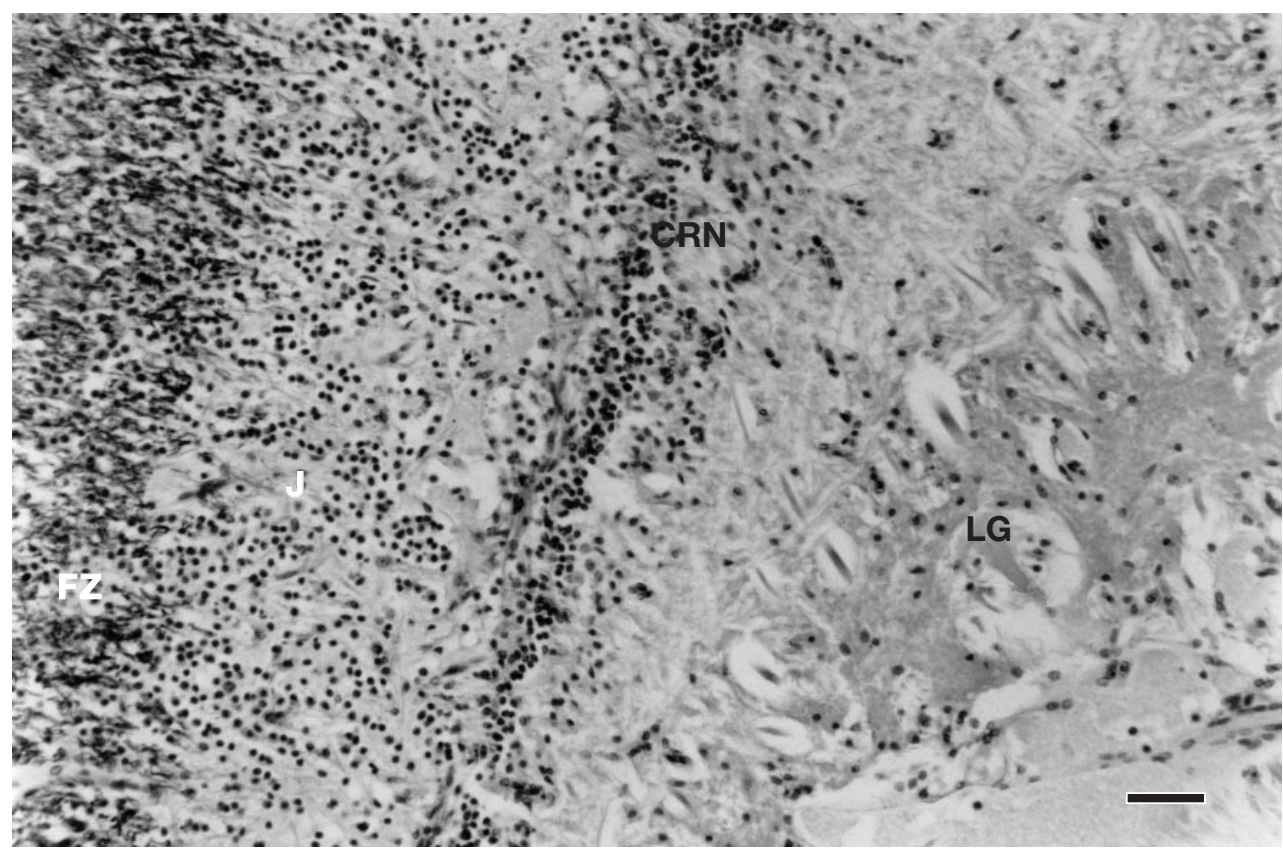

Fig. 1. Penaeus monodon. Infiltration of haemocytes in the lamina ganglionaris (LG) and the fasciculated zone of a badly affected eye. Edema and haemocytes can be seen in the LG, cell rind nuclei (CRN) of the LG, the junction (J) between the lamina ganglionaris and the fasciculated zone (FZ). H\&E stain, 172×, scale bar $=10 \mu \mathrm{m}$ 
Fig. 2. Penaeus monodon. Necrosis and pyknosis of cell rind nuclei (CRN) of the lamina ganglionaris (LG). The region of the CRN of the LG is infiltrated with pyknotic (P) and necrotic haemocytes and eosinophilic interstitual fluid. The neuropil (NLG) of the LG normally consists of nerve and glial fibres running horizontally and vertically, but here they are disorganised. H\&E stain, 340 $\times$, scale bar $=10 \mu \mathrm{m}$

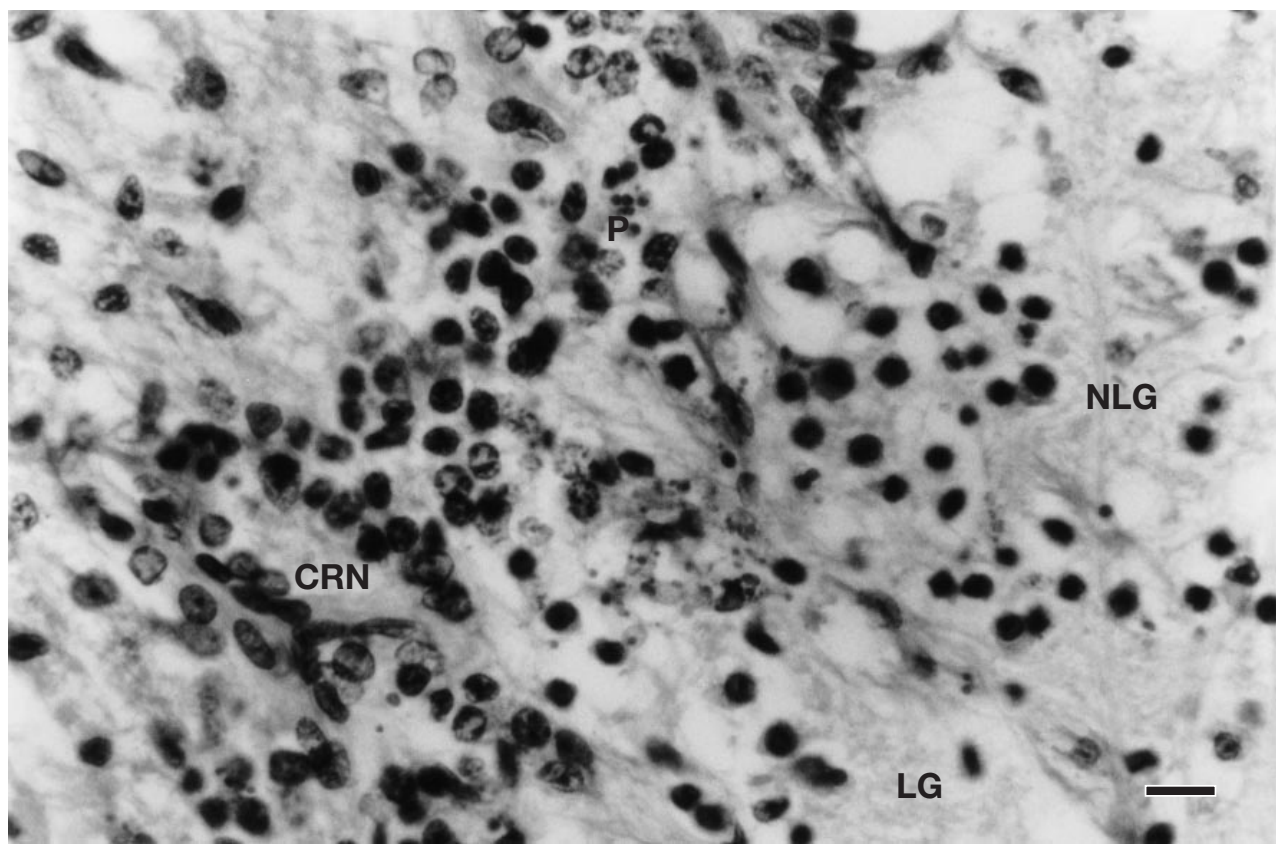

pyknotic cells, inflammatory cells and melanised layers of haemocytes beneath the cuticle (Fig. 4).

\section{Malacia of the eye}

Malacia was observed in 1 to $2 \%$ of moribund shrimp at Farms A, B and C, and it was characterised by necrosis of nervous tissue, vacuolation and vascular proliferation in the medulla ganglia (Fig. 5). Examina- tion of the necrotic nervous tissue revealed multinucleate giant cells. Remnants of cells could also be observed; they were pale and open with chromatin clumps, which suggests they were dead macrophages of the nervous system (Fig. 6). Examination of the optic nerve revealed oligodendroglial cells that were hypertrophied. Also, scattered throughout the distal end of the optic nerve were spaces containing rounded cells with small nuclei, which appeared to be examples of Wallerian degeneration of nerve fibres.
Fig. 3. Penaeus monodon. Infiltration of haemocytes and a focal abscess in the dioptic region of the eye. Relatively normal crystalline tracts (CT), crystalline cones and cone cells (CC) can be seen surrounding a focal abscess (A) of pyknotic and necrotic haemocytes. There is no melanised layer of haemocytes beneath the cuticle (C). H\&E stain, $86 \times$, scale bar $=10 \mu \mathrm{m}$

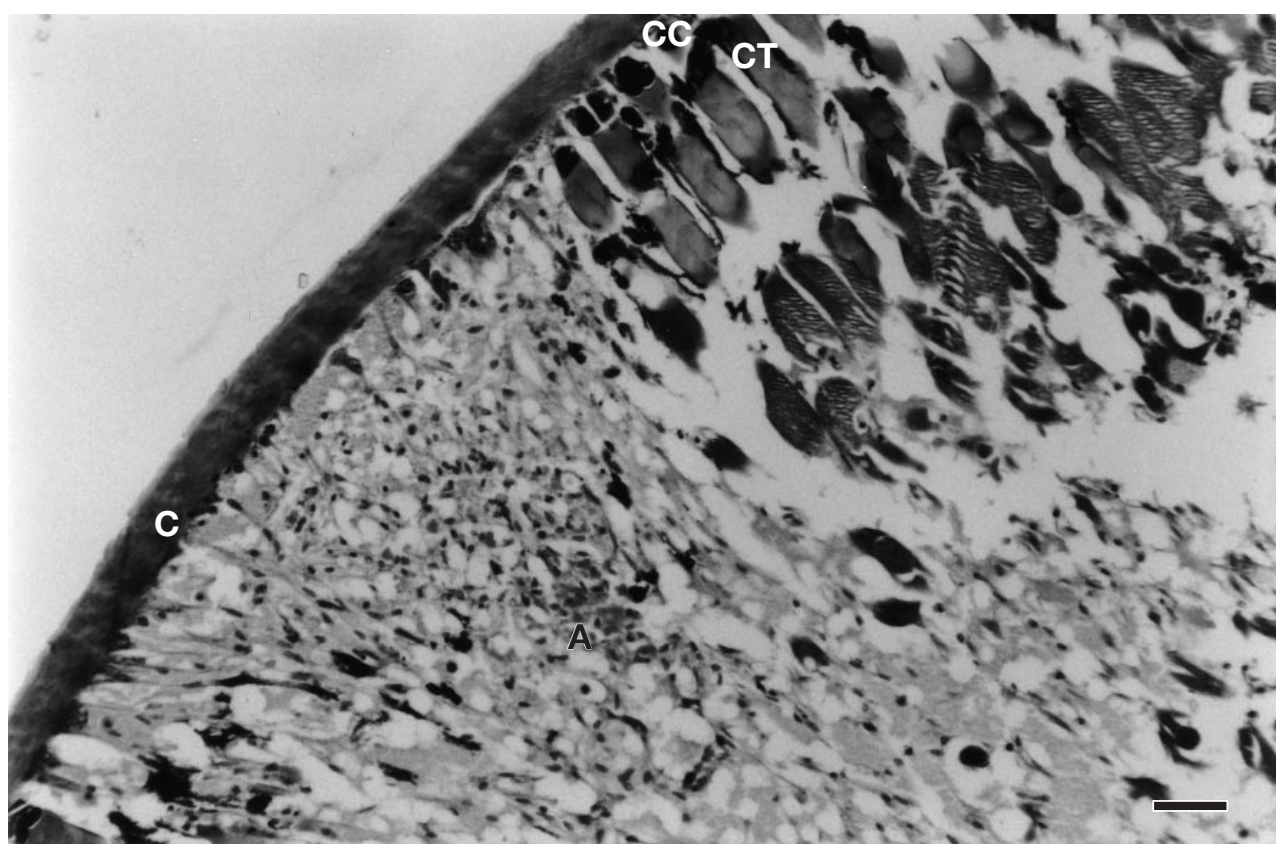




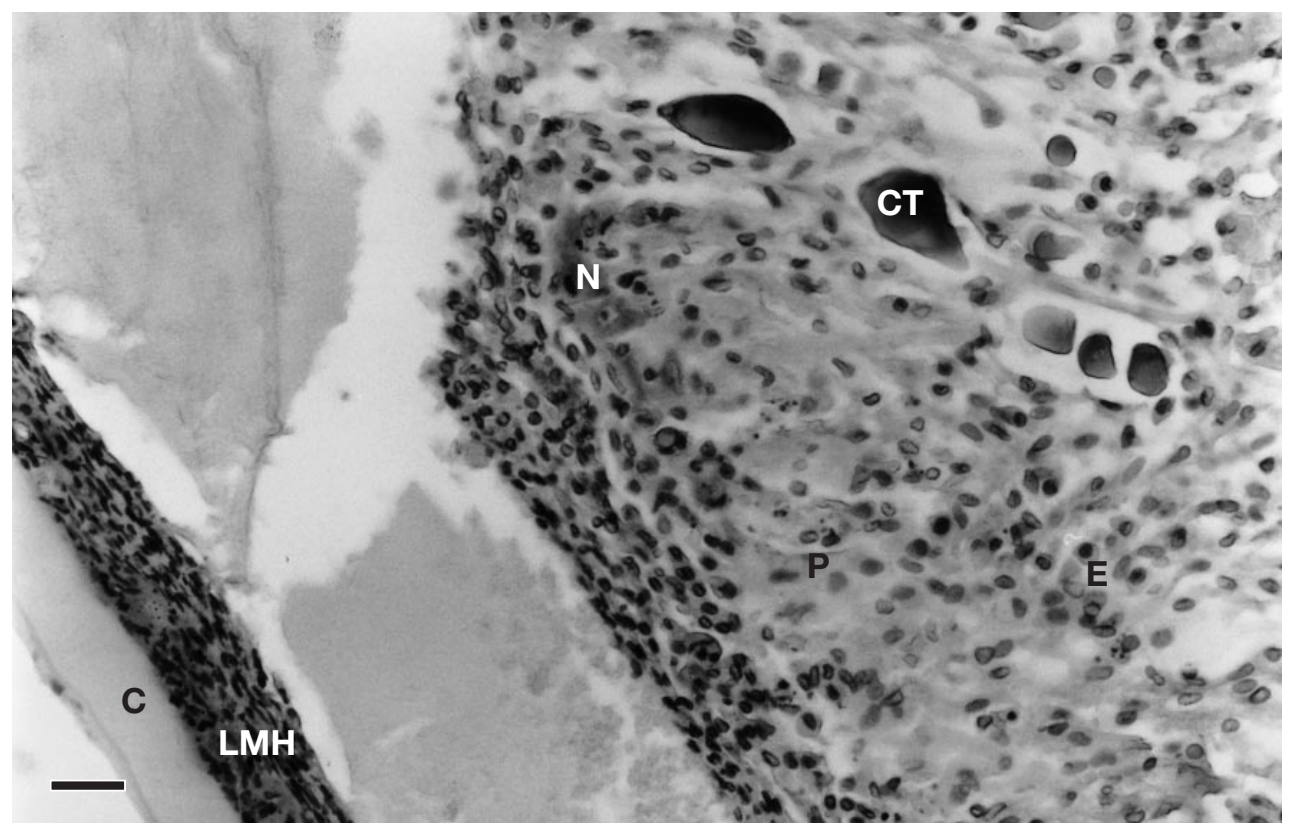

Fig. 4. Penaeus monodon. Advanced granuloma of the eye. Beneath the cuticle is a layer of melanised haemocytes (LMH) and amongst remnant structures of the crystalline tracts (CT) are nodules of haemocytes (N). Pyknotic cells (P) and eosinophilic haemocytes (E) are present within the eosinophilic fibrous tissue. The space between the melanised layer of the cuticle (C) and the underlying tissue is an artefact. H\&E stain, $172 \times$, scale bar = $10 \mu \mathrm{m}$

\section{Bacteriology of shrimp}

In H\&E sections of some eyes there were pale, basophilic, small, rod-shaped bacteria that were typical of Vibrio spp. They were present as free particles in the interstitial fluid and haemolymph as well as in clusters within tissues. In some cases the haemolymph and edema contained vacuoles that were lined with Gram-negative bacteria (Fig. 7). Histological examinations of the cuticle, gills and hepatopancreas of specimens collected during disease events at Farm A in 1994 and Farm C in
1999 also revealed cases of granuloma, melanised cuticles and bacteria as free particles in the lacunae of gills.

Levels of presumptive Vibrionaceae were generally 10 to 100 times higher $(\mathrm{p}<0.01)$ in tissues of moribund shrimp than in the corresponding tissues of healthy shrimp (Table 2). The highest levels of presumptive Vibrionaceae were measured in the hepatopancreas of moribund shrimp (Table 2). The gills of moribund shrimp also had high levels of presumptive Vibrionaceae, but this result may have been boosted by Vibrio spp. in the extensive external fouling. Average levels

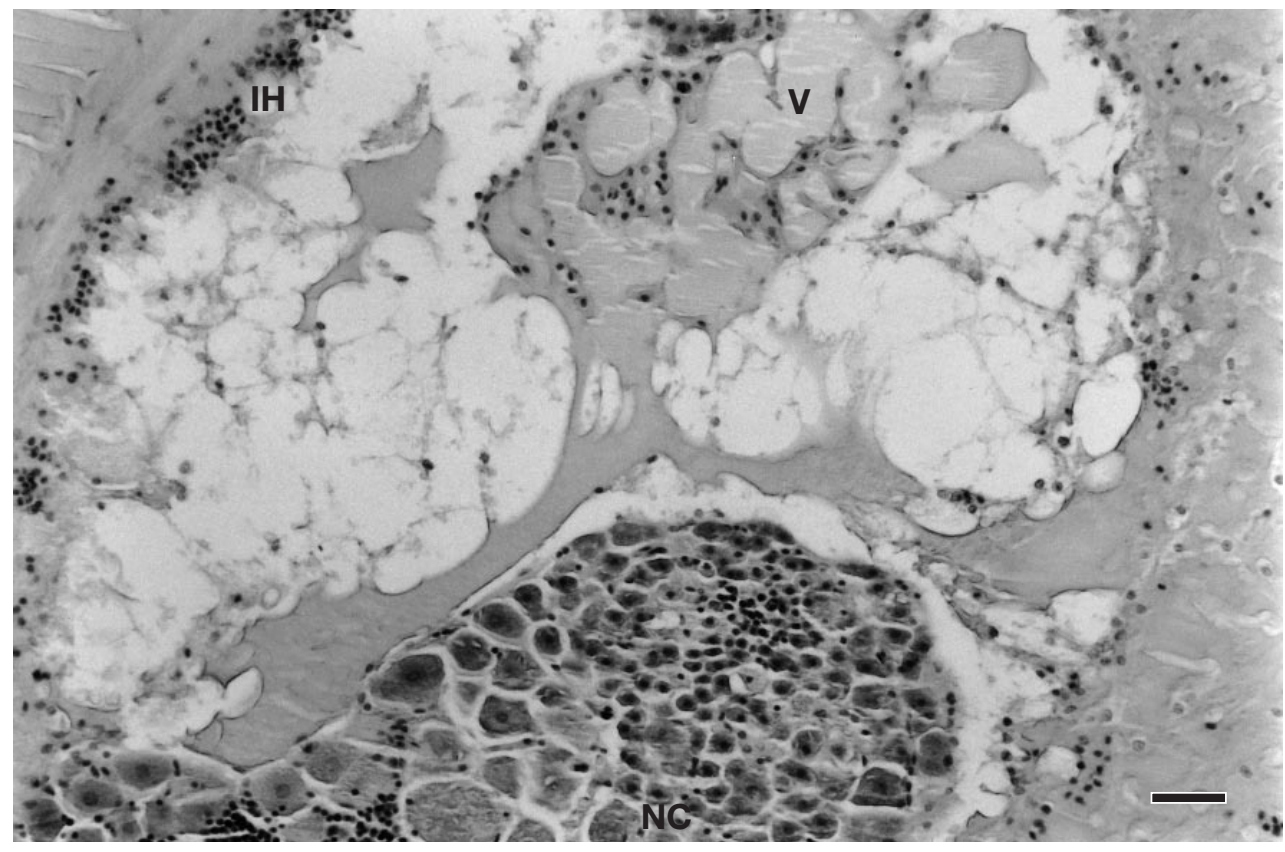

Fig. 5. Penaeus monodon. A lesion, which contains necrotic nerve tissue and vacuoles (V), is located near neurosecretory cells (NC) of the organ of Hanström. An edema containing inflammatory haemocytes $(\mathrm{IH})$ surrounds the necrotic nerve tissue. $H \& E$ stain, $86 \times$, scale bar $=$ $10 \mu \mathrm{m}$ 
Fig. 6. Penaeus monodon. Malacia of the medulla interna. Necrotic nerve tissue contains vacuoles (V), multinucleate cells (MNC) and melanin deposits (MEL). An edema containing inflammatory cells surrounded the necrotic nerve tissue. H\&E stain, $172 \times$, scale bar = $10 \mu \mathrm{m}$

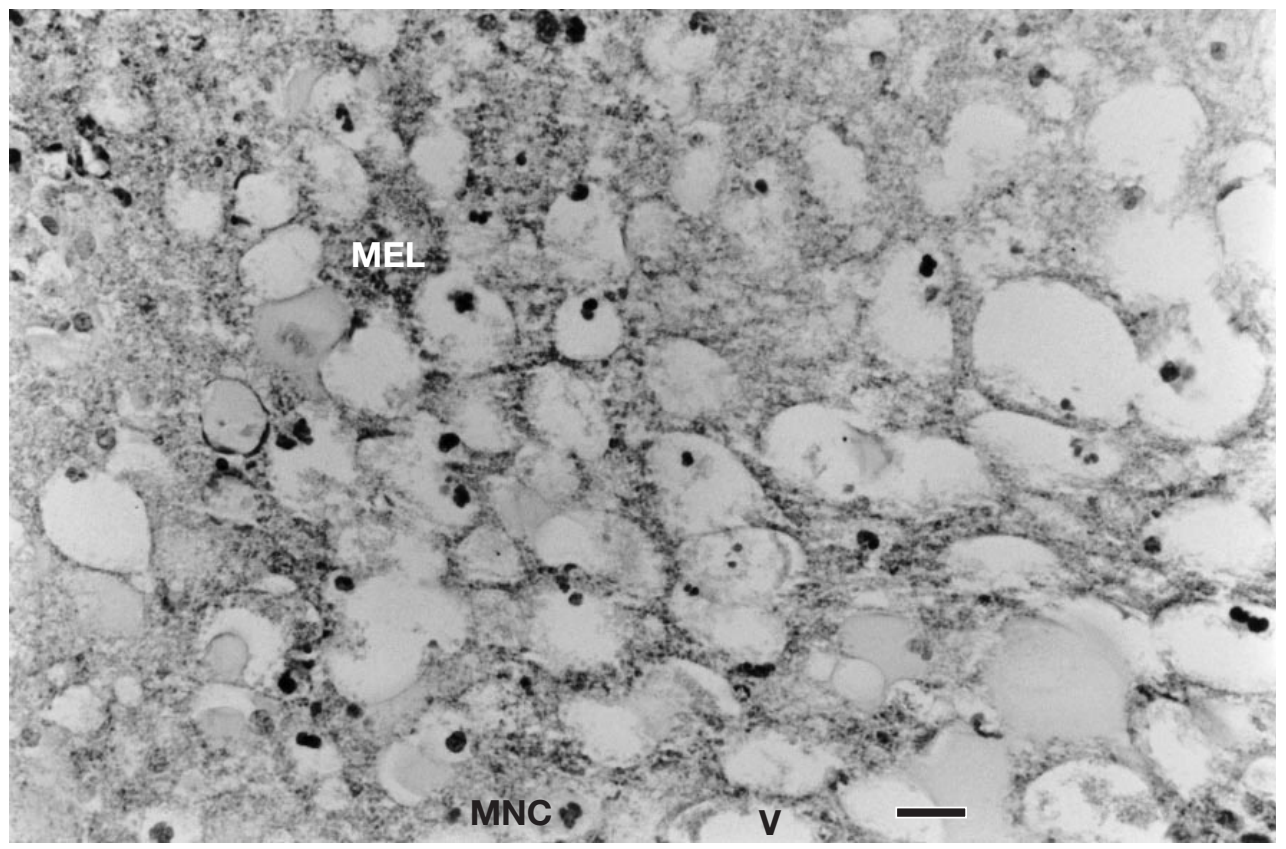

of heterotrophic bacteria in 11 diseased shrimp at Farm C in 1999 were $2.2 \times 10^{5} \mathrm{cfu} \mathrm{g}^{-1}$ in uropods, $2.1 \times$ $10^{3} \mathrm{cfu} \mathrm{ml}^{-1}$ in haemolymph, and $3.6 \times 10^{3} \mathrm{cfu} \mathrm{g}^{-1}$ in eyes. These levels were not significantly different $(\mathrm{p}<$ 0.10 ) from the levels of presumptive Vibrionaceae in the same tissues (Table 2), indicating that most of the culturable bacteria in the 3 types of tissues were Vibrio spp. The most common bacterium isolated on TCBS agar from tissues of moribund shrimp was $V$. harveyi, accounting for $29.6 \%$ of isolates (Fig. 8). Some $51 \%$ of isolates were either $V$. harveyi or $V$. vulnificus.
Histological examinations suggest there are 3 main points of entry to the eye for bacteria. The eye is well supplied with haemal sinuses and lacunae, so in systemic vibriosis, entry would be from the haemolymph. Local sites of infections could occur from bacteria entering through abrasions of the cuticle. Another entry point is the margin around the dioptic portion of the eye. This margin is responsible for expansion during new growth, and it is noticeable in longitudinal sections of the eye as the ventral and dorsal junctions between the crystalline tracts and the eyestalk. In
Fig. 7. Gram-negative bacteria (GNB) in eyes of moribund shrimp. GNB are free particles in haemolymph and interstitial fluid as well as lining vacuoles (V) in the fasciculated zone. Hypertrophied (H) and condensed pyknotic (P) nuclei are also present. Gram stain, 340×, scale bar $=10 \mu \mathrm{m}$

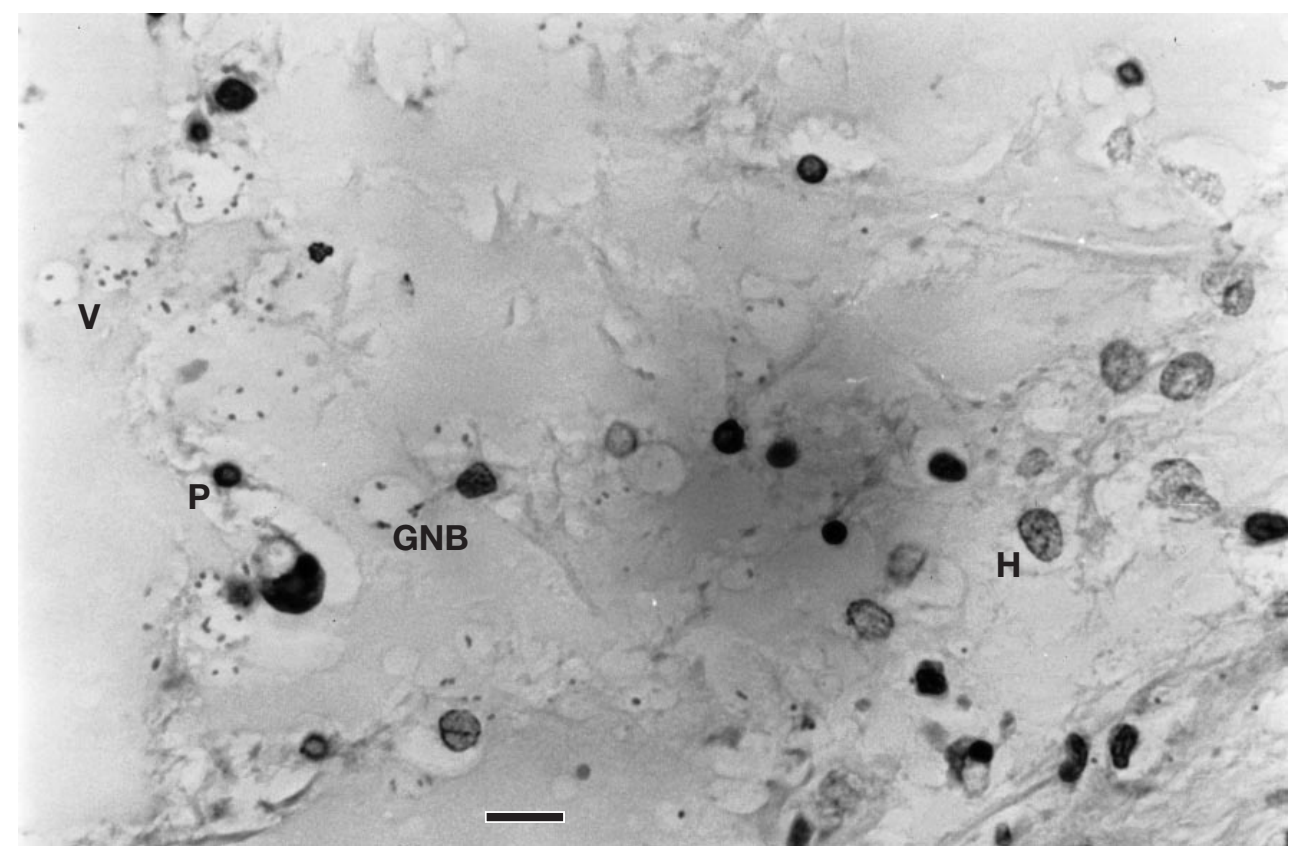


Table 2. Levels of presumptive Vibrionaceae in tissues and organs of Penaeus monodon during disease events. The mean and range are given for the number of tissue samples tested (n) and levels of bacteria are expressed as colony forming units (cfu) per gram $\left(\mathrm{cfu} \mathrm{g}^{-1}\right.$ ) for tissue and $\mathrm{cfu} \mathrm{ml}^{-1}$ for haemolymph. The detection limit (DL) was $10 \mathrm{cfu} \mathrm{ml}^{-1}$ for haemolymph and $5 \times 10^{2} \mathrm{cfu} \mathrm{g}^{-1}$ for other tissues.

\begin{tabular}{|llll|}
\hline Location, year of mortalities & Tissue or organ & Vibrio level in moribund shrimp & Vibrio level in healthy shrimp \\
\hline Farm A, 1994 & Hepatopancreas & $8 \times 10^{6}\left(10^{6}-2 \times 10^{7}\right)(\mathrm{n}=6)$ & $8 \times 10^{5}\left(2 \times 10^{5}-10^{6}\right)(\mathrm{n}=2)$ \\
& Gills & $3 \times 10^{5}\left(4 \times 10^{4}-9 \times 10^{5}\right)(\mathrm{n}=6)$ & All $<\mathrm{DL}(\mathrm{n}=2)$ \\
& Muscle & $5 \times 10^{4}\left(6 \times 10^{3}-8 \times 10^{4}\right)(\mathrm{n}=6)$ & $5 \times 10^{2}\left(\mathrm{DL}-10^{3}\right)(\mathrm{n}=2)$ \\
& Uropods & $10^{5}\left(3 \times 10^{4}-7 \times 10^{5}\right)(\mathrm{n}=11)$ & $2 \times 10^{3}\left(\mathrm{DL}-4 \times 10^{3}\right)(\mathrm{n}=3)$ \\
& Haemolymph & $10^{3}\left(\mathrm{DL}-3 \times 10^{3}\right)(\mathrm{n}=11)$ & All $<\mathrm{DL}(\mathrm{n}=3)$ \\
& Eye & $5 \times 10^{4}\left(10^{3}-2 \times 10^{5}\right)(\mathrm{n}=11)$ & All $<\mathrm{DL}(\mathrm{n}=3)$ \\
& & & \\
\hline
\end{tabular}

healthy shrimp, the ventral junction often had melanised patches and some inflammatory cells. In some moribund shrimp, the junctions were expanded and infiltrated with haemocytes and bacteria. In those cases the dorsal and ventral haemal sinuses of the eyestalk were enlarged and lined with haemocytes.

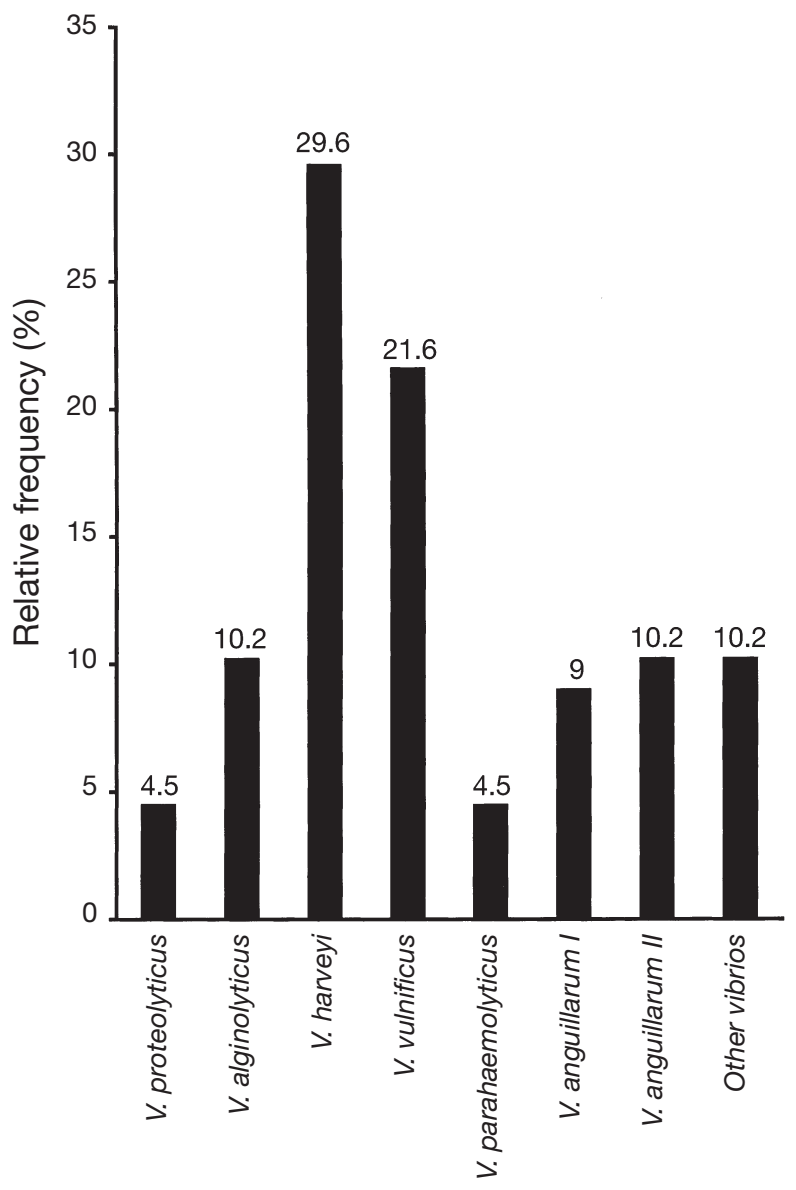

Species of Vibrionaceae

Fig. 8. Relative frequency of strains of Vibrionaceae (Vibrio spp.) $(\mathrm{n}=176)$ isolated from tissue of moribund shrimp with eye lesions
At Farm A in 1994, challenge tests showed that when 6 healthy shrimp were fed diseased shrimp, no mortality occurred during the experiment $(7 \mathrm{~d})$. When a total of 15 healthy shrimp were injected with dilutions of Vibrio isolates from diseased shrimp, $100 \%$ mortality occurred at $2.5 \times 10^{5} \mathrm{cfu} \mathrm{g}^{-1}$ within $15 \mathrm{~min}, 33 \%$ mortality occurred in $24 \mathrm{~h}$ at $2.5 \times 10^{4} \mathrm{cfu} \mathrm{g}^{-1}$, and no mortality at higher dilutions. The $\mathrm{LD}_{50}$ value was estimated at $3 \times 10^{4} \mathrm{cfu} \mathrm{g}^{-1}$ of shrimp. Injection of a total of 12 shrimp with diluted homogenates from the hepatopancreas of moribund shrimp caused $50 \%$ mortality with an inoculum of $5 \times 10^{5} \mathrm{cfu}$ per $20 \mathrm{~g}$ shrimp (i.e. $2.5 \times 10^{4} \mathrm{cfu} \mathrm{g}^{-1}$ tissue). When filtered homogenate from hepatopancreas of moribund shrimp was injected into 6 healthy individuals, no mortality occurred in $7 \mathrm{~d}$. In the tank of control shrimp $(\mathrm{n}=6), 1$ mortality occurred during the experiment.

At Farm B in 1995 when 7 healthy shrimp were fed diseased shrimp, there was no mortality within $7 \mathrm{~d}$. When 4 healthy shrimp were injected with filtered homogenate from pulverised hepatopancreas of moribund shrimp, no mortality occurred in $7 \mathrm{~d}$. No mortality occurred in controls $(n=7)$.

\section{Evidence for viral disease of the eye}

In a search for viruses, the study focused on a disease event at Farm $\mathrm{C}$ in which sexual development was found in moribund shrimp in 1998 (described in 'Overview and pond-side observations'). Histopathology of the eyes of moribund shrimp revealed distended vessels and edema in the lamina ganglionaris and fasciculated zone. Lesions could be observed in the fasciculated zone, retinular cells and crystalline tracts. In the early stages, inflammatory cells infiltrated the fasciculated zone and travelled through the basement membrane, which normally forms a barrier to haemolymph and haemocytes (Johnson 1980). Closer examination of the region around the basement membrane revealed pyknotic cells and degenerating and necrotic inflam- 
Fig. 9. Penaeus monodon. Lesions in the region of the basement membrane (BM). Three sites of breakdown in BM can be seen (arrows). In the fasciculated zone (FZ) there is an immediate area of pyknotic cells (P) and hypertrophied nuclei $(\mathrm{H})$, as well as infiltration of eosinophilic (E) and basophilic (B) haemocytes. Damage to the structure of the rhabdoms (R) is starting to occur. H\&E stain, 340×, scale bar = $10 \mu \mathrm{m}$

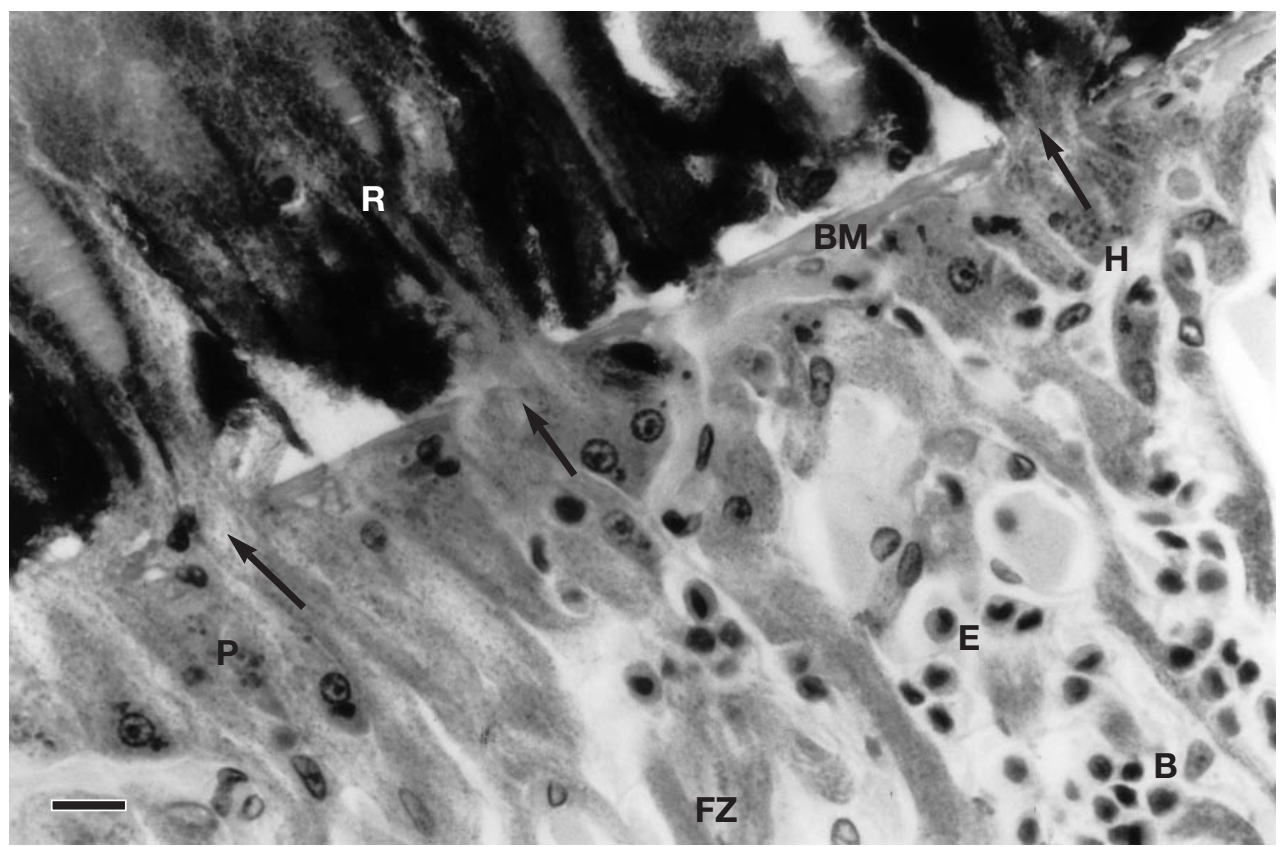

matory cells (Fig. 9). Some inflammatory haemocytes were eosinophilic and others were basophilic. Some nuclei in the fasciculated zone were hypertrophied and either pale or slightly eosinophilic. Breakdown in the structure of rhabdoms was observed and inflammatory cells were found in the crystalline tracts (Fig. 10). At later stages of the disease, damage to the fasciculated zone, retinular cells and crystalline tracts became more extensive. This was also the dominant type of lesion at Farm C in 1999 and similar lesions were observed in about $10 \%$ of specimens from the outbreaks at the other farms (spanning the period 1994 to 1999).

A total of 3 eyes from 3 moribund shrimp were examined by TEM and neither inclusion bodies nor occlusion bodies were found in the nuclei of cells in the lamina ganglionaris, fasciculated zone or retinular cells. However in all eyes, interesting cytoplasmic vesicles (Fig. 11) were observed in the distal portion of the fasciculated zone. This region of the eye contains pigment granules and is proximal to the basement membrane. Vesicles had diameters of 1 to $3 \mu \mathrm{m}$ (range) and they

Fig. 10. Penaeus monodon. Infiltration of haemocytes in the crystalline tracts. After crossing the basement membrane (BM), basophilic haemocytes (B) move between rhabdoms (R) and progress along crystalline tracts (CT) of the eye. Nuclei of retinular cells (RET) can be seen. H\&E stain, $340 x$ scale bar $=10 \mu \mathrm{m}$

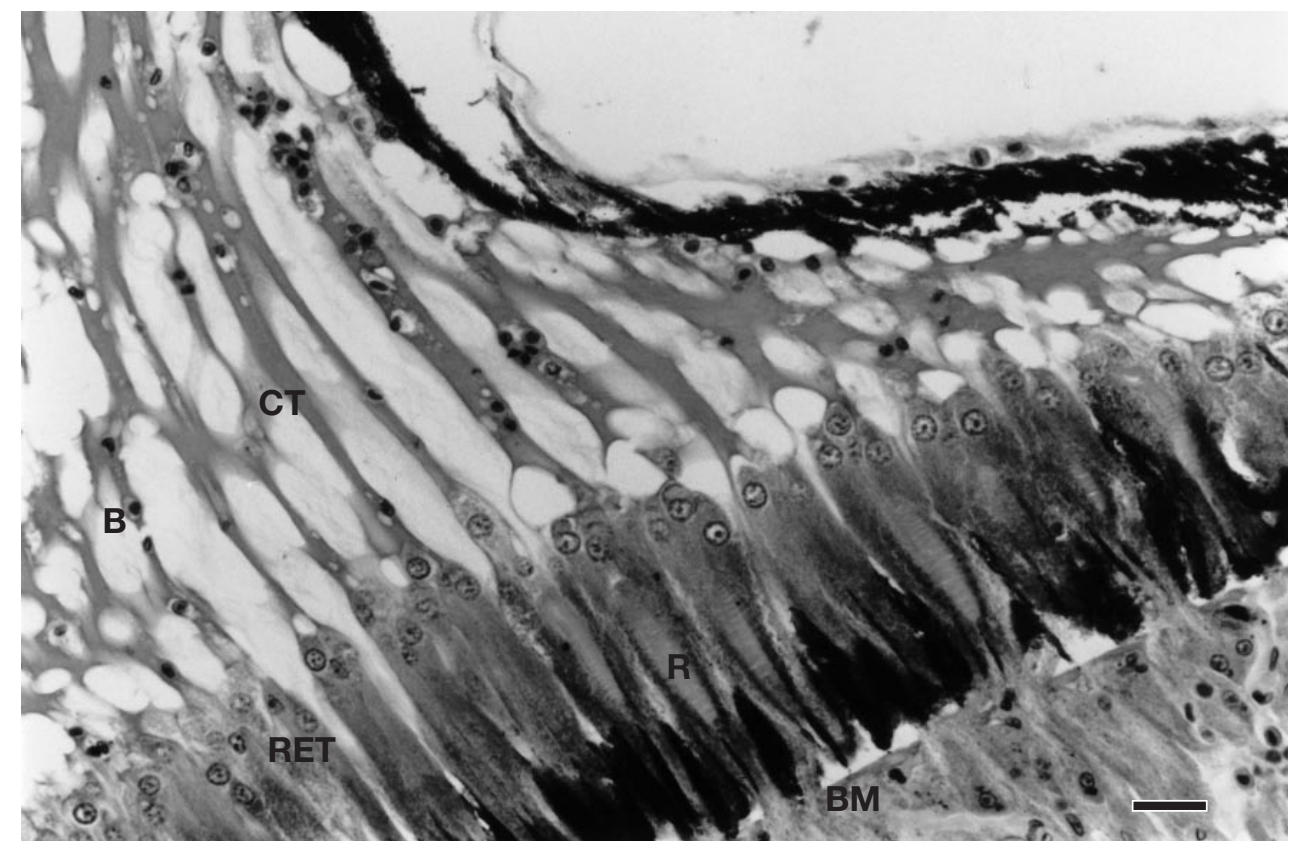




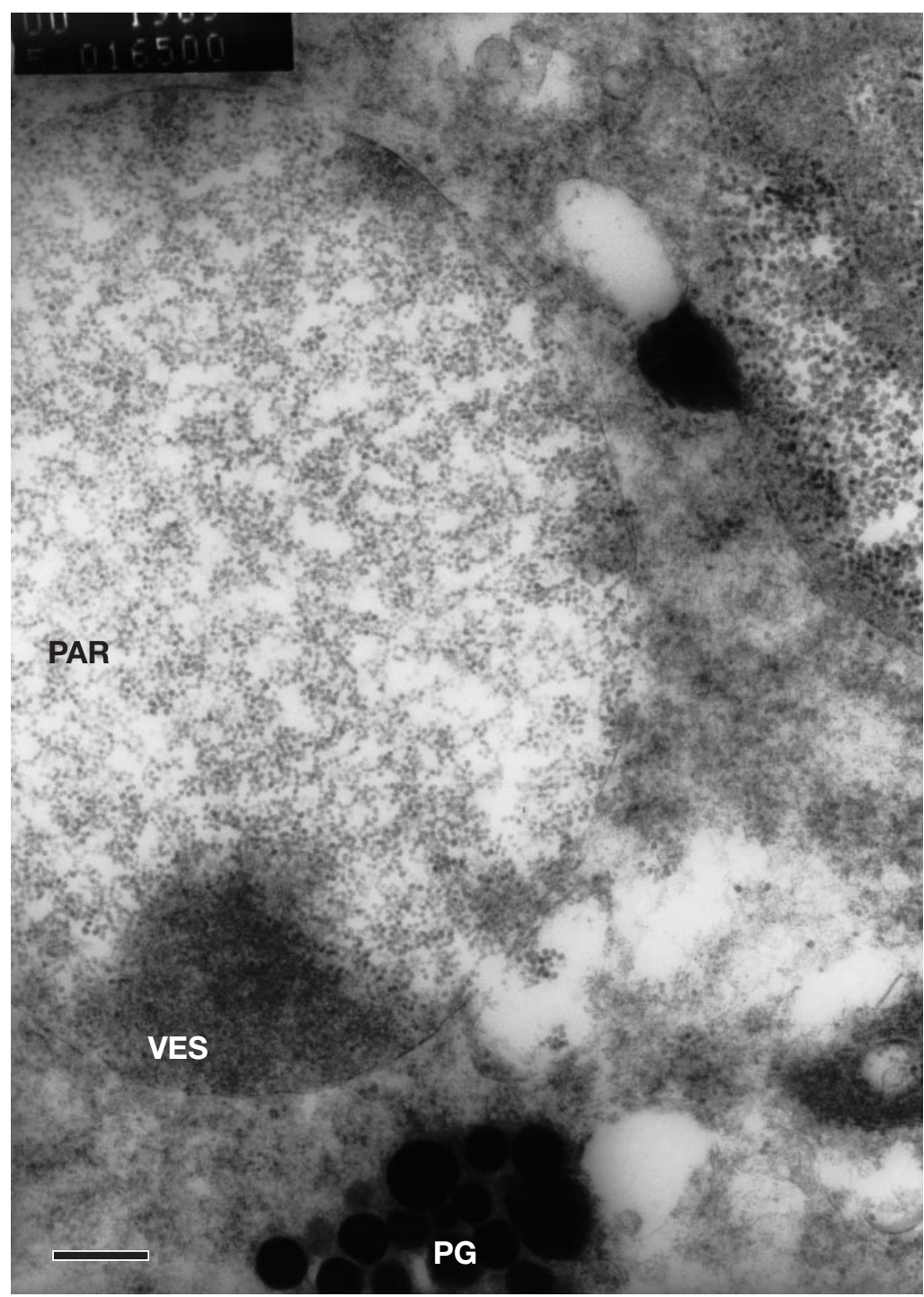

Fig. 11. TEM of vesicles within nerve cells of the fasciculated zone of the eye of moribund shrimp. Cells with vesicles (VES) are located in the fasciculated zone proximal to the basement membrane. The cells contain pigment granules (PG); this is consistent with primary optic nerve fibres of the retinular proximal pigment. The vesicles are $3 \mu \mathrm{m}$ in diameter and contain particles (PAR) $20 \mathrm{~nm}$ in diameter. Some particles also appear to be free in the cytoplasm; however this may be an artefact. Magnification 14 520×, scale bar $=100 \mathrm{~nm}$ suggested that many of the particles may be cross-sections of rod-shaped nucleocapsids, though ribosomes and/or neurosecretory particles could have been present as well. Also, transverse sections of particles, which appeared to be enveloped virions, were observed in cytoplasmic vesicles in the fasciculated zone (Fig. 13). These unidentified enveloped virions averaged $74 \mathrm{~nm}$ in diameter (range $=50$ to $96 \mathrm{~nm}$ ), were spherical or oval in shape and had a nucleocapsid which appeared to have a banded appearance. In comparison, examination by TEM of 3 eyes from grossly healthy shrimp from Farm D failed to show similar vesicles, rod-shaped nucleocapsids or enveloped virions.

TEM indicated that the rod-shaped nucleocapsids were in the primary optic nerve fibres of the fasciculated zone (Figs. $11 \& 12$ ) and this region corresponds to the location of lesions revealed in histopathology (Figs. 9 \& 10). The primary optic nerve fibres run from the retinular cells through the basement membrane to the nerve cells of the lamina ganglionaris. Histological examination of this region in blue crab Callinectes sapidus (p. 140 in Johnson 1980) and Penaeus monodon (Nicol \& Yan 1982) shows that primary optic nerve fibres are axons of the retinular cells and contain pigment granules, which measure 0.12 to $0.40 \mu \mathrm{m}$ in diameter. Similar pigment granules were observed in cells that contained rodshaped nucleocapsids (Fig. 11), and this finding supports the conclusion that the cells were primary optic nerve fibres. The enveloped virions were in unidentified cells in the fasciculated zone.

\section{DISCUSSION}

\section{Limitations of the study}

bled rod-shaped nucleocapsids could be seen within the vesicles at higher magnifications (Fig. 12). The rods averaged $190 \mathrm{~nm}$ in length (range $=130$ to $260 \mathrm{~nm}$ ) and $13 \mathrm{~nm}$ in diameter (range $=10$ to $16 \mathrm{~nm}$ ) and they were distinguished by cross-banding (or a screw-like thread) along their entire length (Fig. 12), which is suggestive of nucleocapsids with helical symmetry. The average distance between threads (pitch) was $3.1 \mathrm{~nm}$ (range = 2.4 to $3.5 \mathrm{~nm}$ ). Close examination of TEM micrographs
There were a number of limitations that impacted on the study. Field trips took place every 6 to $10 \mathrm{wk}$ and disease events that occurred between field trips or at other farms could not be investigated. Also, since the early outbreaks, farmers usually harvest whenever disease problems are first noticed rather than seek assistance or attempt any treatments. These factors 


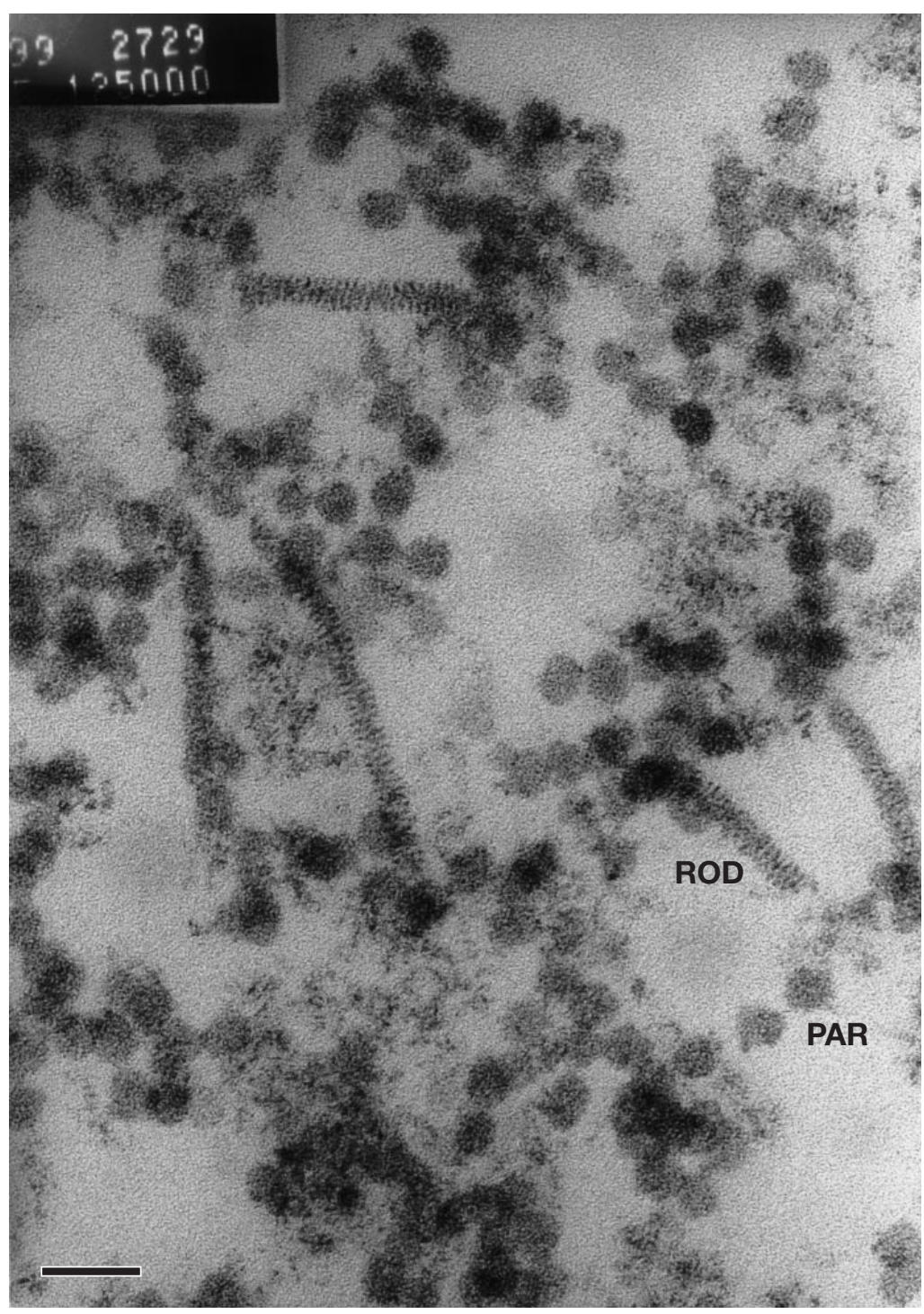

Fig. 12. TEM of vesicle showing particles and rod-shaped structures. High magnification TEM showing particles (PAR) and rods (ROD) within vesicles of primary optic nerve fibres. The rods have helical symmetry and are suggestive of rod-shaped nucleocapsids. In this section the particles are 15 to $26 \mathrm{~nm}$ in diameter, and rods are 155 to $207 \mathrm{~nm}$ long, $15 \mathrm{~nm}$ in diameter and have a pitch (distance between threads) of $3.2 \mathrm{~nm}$. Thin section, magnification $110000 \times$, scale bar $=40 \mathrm{~nm}$

have made it difficult to evaluate the prevalence of the problem. Further, the hypotheses and the focus of the investigation evolved over a number of years, leaving gaps in the study. For example, TEM was not performed on specimens collected in early events. Also, challenge tests were limited to $7 \mathrm{~d}$ and Spann et al. (1997) showed that mortalities in transmission trials often do not start to occur until $8 \mathrm{~d}$ after injection.

The eye was found to be a difficult organ to examine by histology or TEM because it consists of many layers of varying hardness and it is enclosed by a relatively hard, impervious cuticle. Histological sections were easily fragmented and difficulty was encountered during infiltration of specimens with araldite resin for TEM. These problems are consistent with reports of shrinkage and inadequate penetration of fixative in other studies of the eyes of crustaceans and Penaeus monodon (p. 134 in Johnson 1980, Nicol \& Yan 1982).

Finally, the crustacean eye is a complex, dynamic organ that undergoes considerable changes. For example, during the moult cycle of Metapenaeus sp. changes can be observed in the size and composition of neurosecretory cells in the ganglia, the sinus gland and sensory pore of the X-organ (Dall 1965). Also, retinal pigment granules of the retinular cells move very rapidly, so that during light-adaptation, rhabdoms become completely enveloped by retinal pigment in 4 min (Nicol \& Yan 1982). To minimise the possibility of misinterpreting normal changes in the eye, histological examinations were performed on eyes of grossly healthy shrimp from all farms during the study.

\section{Aetiology and epidemiology of eye disease}

Histopathology revealed a range of lesions that were characterised by disorganisation and damage to the nervous tissue and dioptic region of the eye. The investigation identified a rod-shaped virus, which was similar to Gill-Associated Virus (GAV), and an unidentified enveloped virion as possible aetiological agents in one of the disease outbreaks (at Farm C). Vibriosis in eyes and other tissues during that event may have been caused by an opportunistic infection. However, gaps in the data make it difficult to be conclusive about the aetiological agents in the other disease events.

In one disease event at Farm A, the level of presumptive Vibrionaceae in moribund shrimp was high, at around $10^{4} \mathrm{cfu} \mathrm{g}^{-1}$ (Table 2), and challenge tests at Farms A and B showed that these doses caused mortalities when healthy shrimp were injected with Vibrio isolates from moribund shrimp. Filtrates caused no mortalities when injected. These results tend to indicate that the shrimp were suffering from systemic vibriosis. 


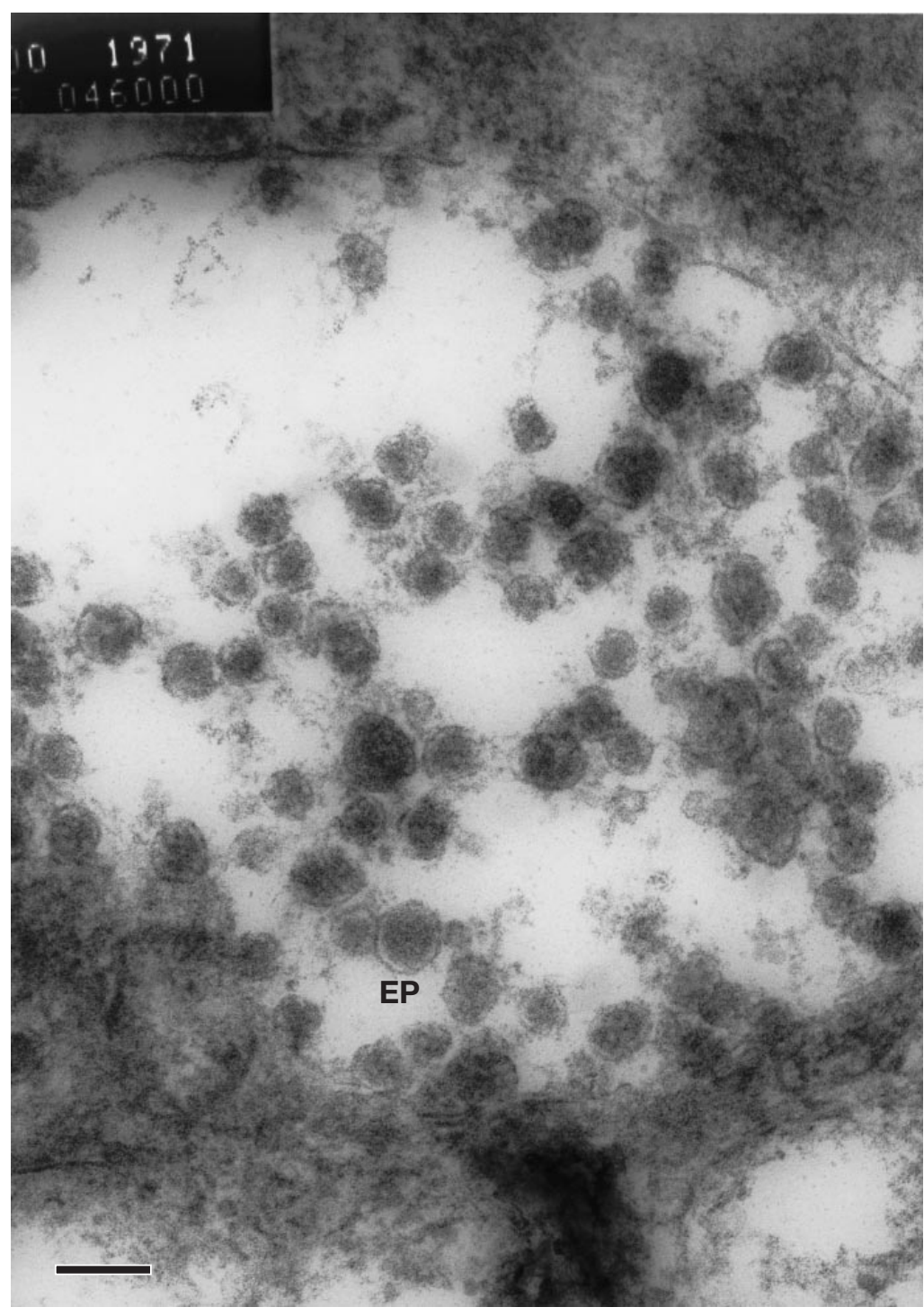

Fig. 13. TEM of enveloped particles (EP) in the proximal region of the fasciculated zone. EP were located in the fasciculated zone near cells with rod-shaped particles. In this section EP are 52 to $78 \mathrm{~nm}$ in diameter. Thin section, magnification $40480 \times$, scale bar $=100 \mathrm{~nm}$

The signs of systemic vibriosis are non-specific and include shrimp resting at the side of ponds, lethargy, loss of appetite, discolouration, necrotic cuticles and abnormal moulting (p. 152 in Chanratchakool et al. 1998). Many of those non-specific signs are consistent with the pond-side observations described here. Also, some of the most common species involved in vibriosis are reported to be $V$. vulnificus and $V$. harveyi (Lightner 1996) and those species were predominant in the results in Fig. 8. Vibriosis is usually characterised by nodules of melanised haemocytes and this was observed in gramuloma (Fig. 4). However, Gram-negative rods were observed in eye lesions as free particles (Fig. 7) and some species of Vibrio may be primary pathogens, capable of producing toxins and causing mortalities at low doses (Harris 1995). So it is also possible that some eye lesions and mortalities may have been caused by virulent species of Vibrio.

The rod-shaped virus that was identified with TEM (Fig. 12) is similar to Yellow-Head Virus (YHV), Lymphoid Organ Virus (LOV) and Gill Associated Virus (GAV). The latter 2 viruses have been found in Penaeus monodon in Australian farms (Spann et al. 1997), while YHV has not been found in Australia. The genomes of GAV and LOV are very similar (Spann pers. comm.) and they are considered to be variants of YHV (p. 26 in AQIS 1998). Like those 3 viruses, the eye virus has helical nucleocapsids, is located in the cytoplasm and is found in vesicles. The nucleocapsids are approximately of the same length for these viruses; however, there are some differences in other dimensions. The nucleocapsids are 16 to $18 \mathrm{~nm}$ wide for GAV and LOV and $15 \mathrm{~nm}$ for YHV, while the nucleocapsids found in the eye were $13 \mathrm{~nm}$ wide. Those differences may have resulted from variations in sample preparation and measurements. However, the separation of threads (pitch) was $7 \mathrm{~nm}$ in GAV (Spann et al. 1997) and $3.2 \mathrm{~nm}$ in the eye virus. This finding could indicate that the rodshaped virus found in the eye is a variant of the other viruses. The genome of the rod-shaped virus of the eye needs to be investigated so that its phylogenetic relationship to these viruses can be determined.

Penaeus monodon with GAV show signs that include red colouration, fouling of the cuticle, lethargy and loss of appetite (Spann et al. 1997). Those are similar to the signs reported here. However, Spann et al. (1997) did not report on the condition of eyes of moribund shrimp. With respect to other related diseases at Australian farms, Mid-Crop Mortality Syndrome is mainly due to GAV (Owens pers. comm.) though it could also be caused by Spawner-Isolated Mortality Virus (p. 61 of Annexe, AQIS 1998) and may have a multiple viral aetiology. Spawner-Isolated Mortality Virus is a small (20 nm), parvo-like virus (Fraser \& Owens 1996, Owens 1997) that causes mortalities in hatcheries and early stages of growout in Australia.

The spread of viral diseases is a major concern for the shrimp farming industry (AQIS 1998). In Australia, 
spawners are obtained from wild stock in northern Australia, and spawners, as well as PL, are transported throughout Australia. This practice has significant implications for the introduction and distribution of viral diseases. The occurrence of similar disease outbreaks at Farms C, D and E in 1999 could be due to the introduction of viral disease from infected batches of PL. The transmission of disease within a pond could occur by cannibalism, since the eye is one of the first organs consumed during cannibalism. The disease could be spread from affected ponds to other ponds within the farm or to nearby farms by contaminated bird faeces, vectors and inappropriate management practices.

The possible triggers for outbreaks of vibriosis or viral disease were investigated but the findings are inconclusive. Possible environmental factors include heavy metals, cyanobacterial toxins, bacterial toxins, $\mathrm{H}_{2} \mathrm{~S}$, biophysical stresses (low levels of dissolved oxygen that may cause hypoxia) and biochemical stresses (high levels of ammonia). These triggers may be exacerbated by nutrient deficiencies and mechanical trauma (abrasion to cuticle). The study found that values for biophysical and biochemical parameters were not unusual for water in shrimp ponds at these farms (Smith 1995) and they were within ranges that are considered appropriate for successful culture of shrimp (p. 71 in Chanratchakool et al. 1998). However, other factors could not be discounted as triggers for disease outbreaks. For example, blooms of planktonic and benthic species of Oscillatoriales were present during disease events and their toxicity at these farms has already been reported (Smith 1996b). Further experimentation of environmental triggers for shrimp diseases is required.

\section{Association between eye lesions and clinical signs of disease}

The eye is a critical endocrine organ that controls most of the physiological and developmental processes of shrimp (Cooke \& Sullivan 1982, Charmantier \& Charmantier-Daures 1998). Hence, it is reasonable to assume that even small lesions in the eye are likely to produce significant problems, which may be manifested in signs of disease such as abnormal moulting, pigmentation or sexual development. The pathological effects of agents such as Vibrio spp., and the 2 viruses reported here in nerves of the eye, may be highly variable, depending on the site of infection, the action of the agent, the response of the immune system and the preferred tissue of the infecting agent. In support of this hypothesis, it is noted that Infectious Hypodermal and Hematopoietic Necrosis (IHHN) causes damage to peripheral nerves and ganglia of the eye (Table 3.1.1 in Lightner 1996). Given the importance of the eye to crustacean metabolism and function, it is interesting that there have been few other reports on diseases of the eye in shrimp. This study found that apart from granuloma and cuticle necrosis, lesions of the eye were not apparent in pond-side examination and this may have caused eye lesions to be overlooked. It is suggested that the eye should be included in routine examination for microscopic lesions in moribund shrimp.

The rod-shaped nucleocapsids, and possibly the enveloped virions, appear to cause damage to the primary optic nerve fibres that run from the retinular cells through the basement membrane to the nerve cells of the lamina ganglionaris. It is probable that this damage could cause partial or severe blindness, resulting in alterations to photo-sensitive neurosecretions from the eye. In some respects the neurosecretions of an infected eye may be equivalent to that of a shrimp in the semi-darkness of deepwater, or of a shrimp after eyestalk ablation. It is hypothesised that the neurosecretions from such an eye may be comparable to those that cause sexual development in healthy shrimp in deep oceanic water.

Sexual maturation of shrimp appears to be a sign that has not been reported as being associated with GAV or other penaeid viral diseases. Transmission studies are planned which could elucidate the relationship between the virus and sexual development. If a relationship can be demonstrated, it may be possible to use the virus in electrophysiological and endocrine studies of the eye. Those studies could improve our understanding of sexual development in Penaeus monodon and could assist in developing better practices for sexual maturation. That work would be important because the investigation of sexual maturation in captive broodstock has been given high priority in a recent report on key areas of research for the shrimp farming industry (Smith \& Phillips 1999).

\section{CONCLUSION}

This study reveals that eye lesions appear to be relatively common and widespread in Penaeus monodon in Australia; they were found in shrimp farms in 2 geographic regions (sub-tropical and warm temperateseparated by $2500 \mathrm{~km}$ ) and during different seasons (from 1994 to 1999). Histological examination of eyes of moribund shrimp revealed a range of lesions that have been broadly described as suppurative inflammation, granuloma, malacia and necrosis of the optic nerve fibres. The pathologies caused severe disorganisation and loss of structure within the nervous tissue and dioptic region of the eye. The pathologies appear 
to be manifestations of different types of eye disease. In one disease event in 1998, a rod-shaped nucleocapsid with helical symmetry, similar to GAV, and an unidentified enveloped virus were found in lesions in the primary optic nerve fibre of the eye. Relatively high levels of pathogenic Vibrio spp. were measured in eyes of moribund shrimp.

Because the eye is a major neuro-endocrine organ in Penaeus monodon, eye lesions may cause a range of signs of disease, which include abnormal pigmentation, less frequent moulting and sexual development. It is suggested that the eye should be included in routine histological examination because eye lesions are usually not apparent in visual examination. Studies of the rod-shaped virus of the eye would be helpful in determining its phylogenetic relationship to GAV. Also, transmission trials may assist in improving our understanding of the effect of eye lesions on disease. Finally, the study indicated that the practice of distributing PL appears to be a major cause of the spread of viral diseases in Australia.

Acknowledgements. This work was funded by research grants from Fisheries Research and Development Corporation (Project No. 98/311) and the University of Western Sydney. The author warmly thanks Richard Callinan (NSW Fisheries) for his enthusiastic support and the reviewers of the manuscript for their helpful comments. Also, assistance was provided by Caroline Wilson (CSIRO Animal Health Laboratories), Kerry Fisher (EMAI), Rod Reece (EMAI), Anne Gleason (EMAI), Ann Simpson Gomes (Sydney University), Renata and David Sandeman (UNSW), Stephen Masters (UWS), Daniel O'Brien (UWS) and Chantelle Agha-Hamilton (UWS). The author also acknowledges the support and hospitality of Australian prawn farmers, particularly Frank and Alan Roberts, Ivan, Melina and Stephen Andrijevic, Sam and Joe Coco, Andrew Date, Col Price, Andrew Fenton and Rob Louden.

\section{LITERATURE CITED}

Anderson IG, Shamsudin MN, Shariff M, Nash G (1988) Bacterial septicemia in juvenile tiger shrimp, Penaeus monodon, cultured in Malaysian brackishwater ponds. Asian Fish Sci 2:93-108

AQIS (1998) Prawn product import risk analysis: technical issues paper. Australian Quarantine and Inspection Service, Canberra

Baumann P, Schubert RHW (1984) Family II. Vibrionaceae. In: Krieg NR, Holt JG (eds) Bergey's manual of systematic bacteriology, Vol 1. Williams and Wilkins, Baltimore, p 516-550

Bell TA, Lightner DV (1988) A handbook of normal penaeid shrimp histology. World Aquaculture Society, Allen Press, Lawrence, KS, p 114

Bern HA, Hagadorn IR (1965) Neurosecretion. Chapter 6. In: Bullock TH, Horridge GA (eds) Structure and function in the nervous systems in invertebrates, Vol 1. WH Freeman \& Company, San Francisco, CA, p 353-429

Boonyaratpalin S, Supamattaya K, Kasornchandra J, Direk- busaracom S, Aekpanithanpong U, Chantanachooklin C (1993) Non-occluded baculo-like virus, the causative agent of Yellow Head Disease in the black tiger shrimp (Penaeus monodon). Gyobyo Kenkyu 28(3):103-109

Cammeron DE, Garland CD, Lewis TE, Machin PJ (1988) A survey of Vibrionaece in Tasmanian coastal waters, with specific reference to bacterial species pathogenic to fish or shellfish. Aust J Mar Freshw Res 39:145-152

Chanratchakool P, Turnbull JF, Funge-Smith SJ, MacRae IH, Limsuwan C (1998) Health management in shrimp ponds, 3rd edn. Aquatic Animal Health Research Institute, Kasetsart University, Bangkok

Charmantier G, Charmantier-Daures M (1998) Endocrine and neuroendocrine regulations in embryos and larvae of crustaceans. Invertebr Reprod Dev 33:273-287

Colorni A (1990) Penaeid pathology in Israel: problems and research. In: Barrett J (ed) Advances in tropical aquaculture, Tahiti, February-March, 1989, Aquacop. Ifremer, Actes de Colloque 9, Tahiti, p 89-96

Cooke IM, Sullivan RE (1982) Hormones and neurosecretions. In: Atwood HL, Sandeman DS (eds) The biology of crustacea, Vol 3. Neurobiology: structure and function. Academic Press, New York, p 205-290

Dall W (1965) Studies of the physiology of a shrimp, Metapenaeus sp. (Crustacea:Decapoda: Penaeidae) II. Endocrines and control of moulting. Aust J Mar Freshw Res 16:1-12

Flegel TW, Sriurairatana S, Wongteerasupaya C, Boonsaeng V, Panyim S, Withyachumnarnkul B (1995) Occurrence, diagnosis and treatment of shrimp diseases in Thailand. In: Browdy CL, Hopkins JS (eds) Swimming through troubled waters. Proceedings of the Special Session on Shrimp Farming, Aquaculture '95, World Aquaculture Society, Baton Rouge, LA p 76-83

Fraser CA, Owens L (1996) Spawner-isolated mortality virus from Australian Penaeus monodon. Dis Aquat Org 27: $141-148$

Giorgetti G (1990) Disease problems in farmed penaeids in Italy. In: Barrett J (ed) Advances in tropical aquaculture. Tahiti, February-March, 1989, Aquacop. Ifremer, Actes de Colloque 9, Tahiti, p 75-87

Harris L (1995) The involvement of toxins in the virulence of Vibrio harveyi strains pathogenic to the black tiger shrimp Penaeus monodon and the use of commercial probiotics to reduce prawn hatchery disease outbreaks caused by $V$. harveyi strains. CRC Aquaculture, Abstract, Bribie Island, Brisbane, Queensland

Hasson KW, Lightner DV, Poulos BT, Redman RM, White BL, Brock JA (1995) Taura syndrome in Penaeus vannamei: demonstration of viral etiology. Dis Aquat Org 23:115-126

Johnson PT (1980) Histology of the blue crab, Callinectes sapidus: a model for the Decapoda. Praeger Publishers, New York, p 429

Johnson PT (1983) Diseases caused by viruses, Rickettsiae, bacteria and fungi. In: Provenzano AJ Jr, Bliss DE (eds) The biology of Crustacea, Vol 6. Pathobiology. Academic Press, New York, p 1-78

Laramore CR, Barkate JA, Persyn HO (1977) Fusarium infection in eyes of mature shrimp (Penaeus vannamei). Texas A \& M University, Texas Agricultural Extension Service, Fish Disease Diagnostic Laboratory, Publ. S9, College Station, TX, USA

Lavilla-Pitogo CR, Baticados MCL, Cruz-Lacierda ER, Dleapena LD (1990) Occurrence of luminous bacterial disease of Penaeus monodon larvae in Philippines. Aquaculture 91:1-13

Lightner DV (1985) A review of the diseases of cultured penaeid shrimps and prawns with emphasis on recent discoveries 
and developments. In: Taki Y, Primavera JH, Llobrera JA (eds) Proceedings of the First International Conference on the Culture of Penaeid Prawns/Shrimps. Aquaculture Department of SEAFDC, Iliolo, Philippines, p 79-103

Lightner DV (1988) Diseases of cultured penaeid shrimp and prawns. In: Sindermann CJ, Lightner DV (eds) Disease diagnosis and control in North American marine aquaculture. Elsevier, Tokyo, p 8-127

Lightner DV (ed) (1996) A handbook of pathology and diagnostic procedures for diseases of penaeid shrimp. World Aquaculture Society, Baton Rouge, LA

Lightner DV, Redman RM (1990) Penaeid virus diseases of the shrimp culture industry of the Americas. In: Fast AW, Lester LJ (eds) Culture of marine shrimp: principles and practises. Chapter 26. Elsevier, Amsterdam, p 569-588

Lightner DV, Bell TA, Redman RM, Mohney LL, Natividad JM, Rukyani A, Poernomo A (1992) A review of some major diseases of economic significance in penaeid prawns/shrimps of the Americas and Indopacific. In: Shariff M, Subasinghe RP, Arthur JR (eds) Diseases in Asian aquaculture 1. Fish Health Section, Asian Fisheries Society, Manila, p 57-80

Nicol JAC, Yan HY (1982) The eye of the grass shrimp Penaeus monodon - a reappraisal of the penaeid eye. Bull Inst Zool Acad Sin (Taipei) 21(1):27-50

Owens L (1993) Description of the first haemocytic rodshaped virus from a penaeid prawn. Dis Aquat Org 16: $217-221$

Owens L (1997) Special topic review: the history of the emergence of viruses in Australian prawn aquaculture. World J Microbiol Biotechnol 13:427-431

Owens L, De Beer S, Smith J (1991) Lymphoid parvo-like virus in Australian prawns. Dis Aquat Org 11:129-134

Smith PT (1995) Characterisation of effluent from prawn farms. In: Bardach J (ed) Sustainable aquaculture '95. Pacific

Editorial responsibility: Timothy Flegel,

Bangkok, Thailand
Congress on Marine Science and Technology, Honolulu, HI, p 327-338

Smith PT (1996a) Physical and chemical characteristics of sediments from prawn farms and mangrove habitats on the Clarence River, Australia. Aquaculture 146:47-83

Smith PT (1996b) Toxic effects of blooms of marine species of Oscillatoriales on farmed prawns (Penaeus monodon, Penaeus japonicus) and brine shrimp (Artemia salina). Toxicon 34:857-869

Smith PT (1998) Effect of removing accumulated sediments on the bacteriology of ponds used to culture Penaeus monodon. Asian Fish Sci 10:355-370

Smith PT, Phillips MJ (1999) Priorities for shrimp research in Thailand and the region. In: Smith PT (ed) Coastal shrimp aquaculture in Thailand: key issues for research. Australian Centre for International Agricultural Research, ACIAR Technical Report No. 47, Canberra, p 93-128

Solangi MA, Lightner DV (1976) Cellular inflammatory response of Penaeus aztecus and Penaeus setiferus to the pathogenic fungus, Fusarium sp., isolated from California brown shrimp, Penaeus californiensis. J Invertebr Pathol 27:77-86

Spann KM, Cowley JA, Walker PJ, Lester RJG (1997) A yellow-head-like virus from Penaeus monodon cultured in Australia. Dis Aquat Org 31:169-179

Takahashi Y, Itami T, Kondo M, Maeda M, Fujii R, Tomonaga S, Supamattaya K, Boonyaratpalin S (1994) Electron microscopic evidence of bacilliform virus infection in Kuruma shrimp (Penaeus japonicus). Fish Pathol 29:121-125

Vesk M, Rees T (1986) Electron microscopy: notes for a short workshop and training course in biological electron microscopy. CSIRO Marine Laboratories, Hobart, p 26

West PA, Colwell RR (1984) Identification and classification of Vibrionaceae - an overview. In: Colwell RR (ed) Vibrios in the environment. John Wiley, New York, p 285-363

Submitted: December 27, 1999; Accepted: September 11, 2000 Proofs received from author(s): November 6, 2000 